\title{
Mineral raw material disintegration mechanisms in ball mills and distribution of grinding energy between sequential stages
}

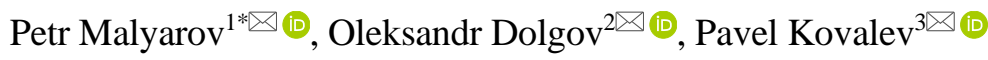 \\ ${ }^{1}$ Platov South Russian State Polytechnic University, Novocherkassk, 346428, Russian Federation \\ ${ }^{2}$ Dnipro University of Technology, Dnipro, 49005, Ukraine \\ ${ }^{3}$ LLC "Resurs”, Stavropol, 355000, Russian Federation \\ *Corresponding author: e-mail aledolgm@gmail.com, tel. +380677913889
}

\begin{abstract}
Purpose. To study the mechanism of mineral raw material particles destruction, the rational distribution of grinding energy between successive grinding stages in ball mills, and the development of engineering methods for redistribution of technological flows in grinding schemes to reduce specific energy consumption.

Methods. Experimental studies of the breakage mechanism were carried out using a physical model of a ball mill operated in the batch mode taking into account the similarity theory. For comparative studies of dry and wet grinding, quartz sand and crushed marble products with a particle size of $+0.25 \ldots-0.5 \mathrm{~mm}$ were used. The selection of the grinding energy distribution rational parameters between successive stages of ball grinding was carried out by general testing at the concentrator plants of Armenia, Russia, and Uzbekistan.

Findings. The materials resulting from studying processes of grinding mineral raw materials in ball mills are presented. It was established that the mineral raw particles destruction in ball mills occurs within the layer as a result of the layers discrete sliding of the ball charge along the ascending trajectories while effectively filling the free space between the balls with the material to be crushed. A technique was developed for evaluating the efficiency of grinding energy distribution between successive stages on the basis of the established laws of mineral raw material particles destruction. Methods for redistributing the grinding energy between the first and second grinding stages are proposed. The methods for the rational distribution of grinding energy between mills of the first and second stages, using drum screens, was developed and implemented in the practice of concentrator plants.

Originality. The authors established the dependences of the grinding material content of the size $-100 \mu \mathrm{m}$ on the free space filling coefficient with the material for sand and marble during dry and wet grinding. The mechanism of the mineral raw particle destruction in the layer during discrete sliding between the charge layers on the ascending trajectories is disclosed.

Practical implications. The proposed methodology for evaluating the efficiency of grinding energy distribution made it possible to develop and implement into the concentrator plants practice the techniques for redistributing grinding energy between successive stages with significant economic effect.
\end{abstract}

Keywords: mill, grinding, slippage, grinding energy, drum screen

\section{Introduction}

When grinding mineral raw material in the process of ore preparation, various types of grinding equipment are used. For its rational choice, it is necessary to present the mechanisms and energy intensity of the destruction processes for each specific type of equipment [1]-[6].

Mineral particle breakage in drum mills is thought to be a result of impact interactions and abrasion [1]. Such simplified approach does not allow to fully understand the kinetics of the grinding process. The classical theory of charge movement in drum mills does not consider fundamental differences in the patterns of charge distribution and movement in the cross section of ball mills and semiautogenous (SAG) mills. The processes of new size classes formation in time during the breakage of mineral feed particles characterize the grinding kinetics [8]-[10]. The destruction mechanism of mineral raw materials in all types of drum mills is influenced by:

- the parameters of the mill mechanical mode operation;

- the solid to liquid ( $\mathrm{S}: \mathrm{L}$ ) ratio of the slurry;

- the amount of material to be ground in the volume of grinding media;

- other technical and process parameters of disintegration [11], [12].

Until now, the particle breakage mechanisms under dry and wet grinding in drum mills have not been adequately studied [13]. 
The objectives of this study are as follows:

- studying the mineral raw materials destruction mechanisms in ball mills;

- determining the effect of the amount of ground material in the volume of grinding media on the kinetics of grinding;

- development of a methodology for determining the rational grinding energy distribution in grinding sections between successive stages;

- development of the ways for the grinding energy redistribution between successive stages.

\section{Analysis of the mineral raw materials destruction mechanisms in ball mills}

Breakage mechanisms of the mineral feed were studied in a physical model of a ball mill, based on the theory of similarity [14]. The ratio of the mineral feed amount to the grinding media and the mechanical operation parameters of the physical model matched the respective values in the entire range of operation of full-scale mills.

Figure 1a shows the distribution of the charge in the cross section of the ball mill. The levels of force interaction between the charge elements in different zones are significantly different in magnitude. The most loaded areas are 1, 2, 3, where intensive grinding takes place. In reality, the charge movement in the mixed mode differs from that described in classical theory. On ascending trajectories, the movement involves slippage between the layers around the center of the charge motion, which does not coincide with the geometric center of the mill. Slippage between the charge layers on ascending trajectories leads to the fact that the outer layer outline has in reality three phases. Individual sections of descending trajectories are parabola-shaped, and before hitting the lining they move along the outer layer of the toe. Slippage in the lower part of the curve involves major force interactions between the charge layers. In wet grinding, the level of the liquid phase of the slurry is located above the toe zone, which provides hydraulic braking of the balls traveling in the direction of the lining. Otherwise, charge distribution across the zones is almost the same in dry and wet grinding.

Figure 1b shows the trajectory of the first inner ball layer relative to the outer layer. It is found that in some cases, slippage between the charge layers on ascending trajectories is discrete. To study the breakage mechanism of the mineral feed particles in combination with the nature of slippage between the charge layers, several series of experiments were carried out. For a comparative study of dry and wet grinding, quartz sand and crushed marble products sized $+0.25 \ldots-0.5 \mathrm{~mm}$ were used.

Quartz sand is a mineral, in which all grains have the same physical and mechanical properties, and the share of clay does not exceed $1 \%$. The composition of marble includes pelitic mineral fractions crushed to a powdered state which, when the splices are opened, form ultra-fine classes. The liquid phase of the slurry containing ultra-fine classes is an elastic-viscous medium.

In wet and dry grinding, the ratio of the mineral feed $V_{m f}$ to the ball charge of the mill $V_{b c h}$ was adopted as a variable. We refer to this ratio as the filling coefficient of the grinding media volume with the mineral feed:

$$
K=\frac{V_{m f}}{V_{b c h}} .
$$

(a)

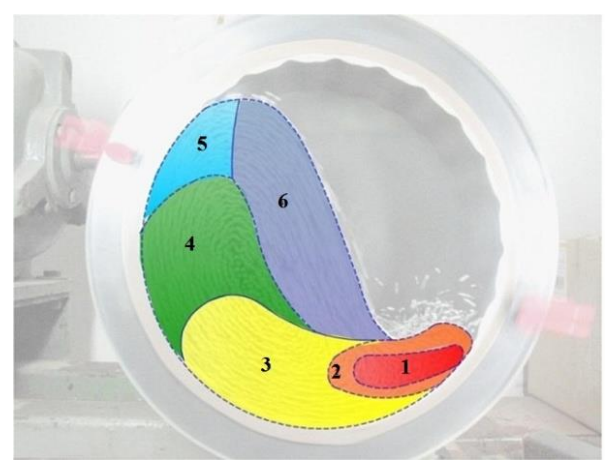

(b)

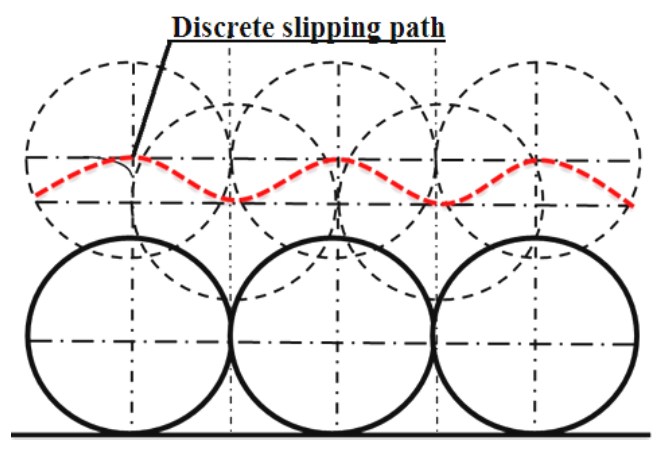

Figure 1. Scheme of the charge distribution in the cross section of the ball mill drum: (a) schematic charge distribution by zones; (b) potential ball stacking along the zones on the ascending trajectories

In each series of experiments, the minimum amount of material to be ground was taken so that it could be freely located in the spaces between the balls. The maximum amount of the material to be crushed should provide a stable cushion between the layers on the ascending trajectories.

Interpretation of high-speed video showed that in dry and wet grinding, under the conditions of direct contact between the balls, slippage between the ball layers is discrete. Short stops, accompanied by dynamic force interaction between the balls, during discrete slippage occur when the balls of the inner and outer layers come into direct contact. Discrete slippage, and, accordingly, dynamic force interaction between the ball charge layers, ceases with the formation of a stable layer of ground mineral feed between them.

To study the grinding kinetics in ball mills, laboratory grinding studies were conducted with various ratios of the feed volume to the volume of the ball charge in dry and wet grinding. Natural washed quartz sand with a bulk density of $1.35 \mathrm{~g} / \mathrm{cm}^{3}$ and ground marble with a bulk density of $1.34 \mathrm{~g} / \mathrm{cm}^{3}$ were fed into the mills. A common feature of ground quartz sand and ground marble is that within the specified mechanical parameters, the material to be ground is distributed unevenly along the cross section zones.

It was visually found that in wet grinding most of the ground feed is concentrated in the lower part of the drum, while the toe zone is completely filled with the liquid phase of the slurry, dominated by fine classes.

In dry grinding, some of the material is carried away by the balls of contacting layers along the descending trajectory. This phenomenon is explained by the fact that the internal friction in the presence of the liquid phase is lower than in 
dry grinding, keeping the slurry between the grinding media in the lower part of the mill drum under the action of gravitational forces.

The size of the mineral feed in both cases was $+0.25 \ldots$ $-0.5 \mathrm{~mm}$. The grindability was assessed by the size $-100 \mu \mathrm{m}$. The grinding time in all experiments was $t=6$ minutes.

Figure 2a shows the relationship between the share of the size $-100 \mu \mathrm{m}$ in dry and wet grinding of washed quartz sand, and the filling ratio $K$, while Figure 2 b shows the same relationship in the grinding of marble.

(a)

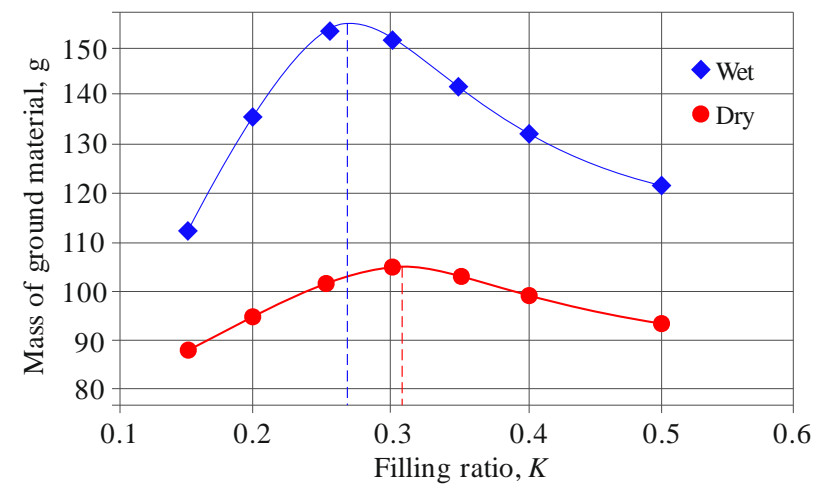

(b)

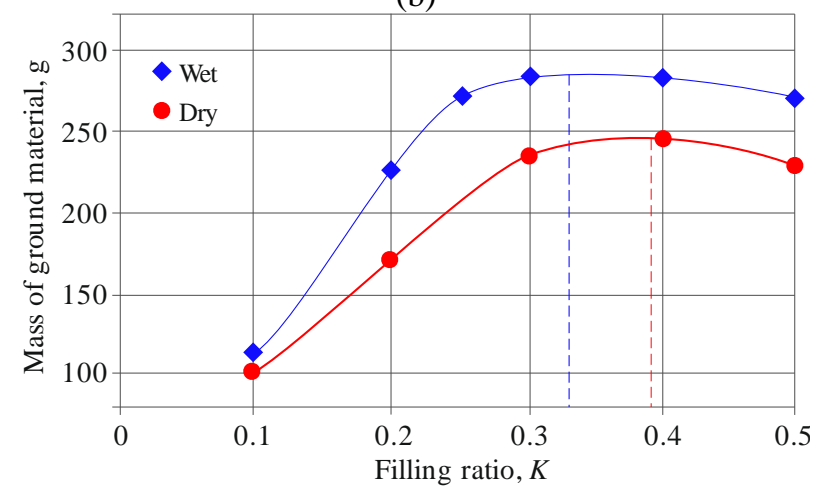

Figure 2. The relationship between the share of ground material of the size $-100 \mu m$ and the filling ratio $K$ : (a) when grinding quartz sand; (b) when grinding marble

Analysis of the found relationships, as well as photo and video materials, led to the following conclusions:

- in the wet grinding of quartz sand (Fig. 2a) and crushed marble (Fig. 2b), the yield of the size $-100 \mu \mathrm{m}$ is higher than that in dry grinding for all filling ratio values $K$;

- the most intensive grinding occurs when the voids between the balls on the ascending trajectories are completely filled with to the material to be ground. Discrete slippage between the balls layers, when filling the free spaces with particles of the material, ensures the transfer of dynamic forces between them and, as a result, breakage within the layer;

- a further increase in the share of material to be ground in the charge leads to the formation of a stable layer between the ball layers and a decrease in mill yield in the $-100 \mu \mathrm{m}$ class. Here, slippage ceases to be discrete and assumes a continuous nature;

- the lowest values of yield of the size of $-100 \mu \mathrm{m}$ correspond to low values of the filling ratio, when the voids between the balls are not completely filled with the material and there are no force interactions between the mineral parti- cles. In wet grinding, this phenomenon is characteristic of low solid to liquid $(\mathrm{S}: \mathrm{L})$ ratios.

In the operation of concentrator plants, this is accompanied by the fact that the performance of the ball mills at the second stage of grinding is in some cases significantly lower than the performance of ore grinding mills [15], [16], including the final product fed to concentration. Such phenomena were noted in a comparative study of the formation rate of final sizes in the grinding mills of the first and second stages at the concentrator plants of Almalyk MMC in Uzbekistan, Zangezur Ore Mining and Processing Project in Armenia, as well as at the operations of Norilsk Nickel and Urup Ore Mining and Processing Project in Russian Federation. This leads to excessive specific energy consumption in grinding circuits.

Yield of the $-100 \mu \mathrm{m}$ size is greater when grinding marble than when grinding quartz sand. This is due to the difference in the mineral composition of quartz sand and crushed marble of the same size.

Washed silica sand containing quartz is a monomineral and homogeneous rock with high physical and mechanical properties and chemical resistance. The marble used in the experiment is a polymineral metamorphic rock composed of calcite (calcium carbonate) with mineral and organic inclusions and impurities. Marble contains minerals such as pyrite, feldspar, hematite, limonite, quartz, and chalcedony [17]. These impurities affect the physic and mechanical properties of marble.

Unlocking intergrowth in marble mineral grains leads to the release of mineral particles of low strength, which are ground to a pelite fraction with greater speed. Clay minerals are absent in the composition of the original marble rock, but relatively soft rock compared to quartz (biotite, hornblende with a Mohs hardness of 3-5) is present, which leads to the formation of a large pelite fraction during grinding.

From the diagrams (Fig. 2), it is obvious that the formation of the classes containing the pelite component during marble grinding leads to an increase in the filling ratio value $K$, corresponding to the maximum yield of the class $100 \mu \mathrm{m}$, by $22-25 \%$ compared to quartz sand.

Grinding of mineral feed with inclusions of soft minerals is subject to the laws of selective grinding as in hydrometallurgy [18]-[20]. In presence of a liquid phase, the pelite fraction of soft minerals reduces the concentration of stresses at the points of contact between the coarser particles, turning concentrated loads into distributed ones.

The authors in [21], [22] present a computer simulation of the breakage process of particles in the layer and prediction of a particle size distribution in grinding rollers. In this case, there is a concentration of stresses in the places of contact between the particles. In ball mills, when the drum is in efficiently filling mode with the material to be ground, in both dry and wet grinding, the voids between the larger particles are filled with finer particles. Unlike grinding rollers, mineral feed particles in the mill during a single revolution are subjected to multiple dynamic impacts by the balls. The result is that even when grinding minerals possess similar strength properties, different sizes are present in the mill product due to diversity of the nature of breakage and a significant variation in the sizes of the initial feed particles. Reducing the internal friction in the slurry and the more compact filling of the voids between the balls by the particles of the ground material increases the frequency of impact interactions at a constant interaction energy, which leads to the high performance of wet grinding. 
With volumetric loading, the energy hypothesis can be applied, according to which the limiting state at a point occurs when the strain energy due to distortion assumes a limiting value:

$$
U_{l}=\frac{1+\mu}{6 E} 2 \sigma_{e q}^{2} .
$$

In this case equivalent stresses can be determined from the known equations [22]:

$$
\sigma_{e q}=\frac{1}{\sqrt{2}} \sqrt{\left(\sigma_{1}-\sigma_{2}\right)^{2}+\left(\sigma_{2}-\sigma_{3}\right)^{2}+\left(\sigma_{3}-\sigma_{1}\right)^{2}},
$$

or

$$
\sigma_{e q}=\frac{1}{\sqrt{2}} \sqrt{\left(\sigma_{x x}-\sigma_{y y}\right)^{2}+\left(\sigma_{y y}-\sigma_{z z}\right)^{2}+\left(\sigma_{z z}-\sigma_{x x}\right)^{2}+6\left(\tau_{x y}^{2}+\tau_{x z}^{2}+\tau_{y z}^{2}\right)} .
$$

Expressions for stress and strain intensity through the principal stresses and strains are represented as:

$$
\begin{aligned}
& \sigma_{i}=\frac{\sqrt{2}}{2} \sqrt{\left(\sigma_{1}-\sigma_{2}\right)^{2}+\left(\sigma_{1}-\sigma_{3}\right)^{2}+\left(\sigma_{2}-\sigma_{3}\right)^{2}} ; \\
& \varepsilon_{i}=\frac{\sqrt{2}}{2 \cdot(1+\mu)} \sqrt{\left(\varepsilon_{1}-\varepsilon_{2}\right)^{2}+\left(\varepsilon_{1}-\varepsilon_{3}\right)^{2}+\left(\varepsilon_{2}-\varepsilon_{3}\right)^{2}} .
\end{aligned}
$$

Analytically, the breakage of mineral feed particles in the layer between the moving balls of the mill charge can be described by the finite element method (FEM) based on the well-known works [24] by analogy with studies on the destruction of the ore raw materials in roller presses [21]-[23].

The strength and elasticity properties of mineral feeds are complex, due to the presence of internal structural defects and various properties of the rock minerals ranging from strong quartzites to pelite fractions. The experimental works [25], [26] are devoted to the methods for determining these characteristics.

Within the framework of breakage strain of mineral particles according to Hooke's law, the principle of virtual displacements is most widespread. The primary cause of ore breakage is critical strain, leading to stress concentration in the areas of heterogeneity [27], [28]. In practice, breakage can be visualized by building a strain diagram, the force strain relationship $(F-\Delta x)$. In the elastic strain region, this relationship is described by Hooke's law: $F=k \cdot x$, where $k$ is the stiffness coefficient (depending on the properties and geo-metry of the body). Breakage occurs when the critical strain $\Delta x_{c r}$ is reached in the local area and the ultimate resistance forms, which is perceived as an external destructing force $F_{c r}$. Quasistatic deformation allows considering the resistance force as identical to a force applied to the material at any moment of exposure.

When grinding in a ball mill, the work of external forces applied to the fed material can be classified as follows:

1) $W_{P}$ - work performed by concentrated (interaction) forces;

2) $W_{q}$ - work performed by the load distributed on the surface.

The work performed by the bulk forces of the particles themselves, for example, by the forces of gravity, in ball mills does not have a decisive effect on the processes of breakage due to their insignificance compared to the size and mass of the grinding media. The gravitational forces of the grinding media affect the processes of breakage in the toe zone, i.e. where the breakage of minerals occurs due to impact during the conversion of potential energy into the kinetic energy of grinding. Impact grinding occurs between the balls, as well as between the balls and the lining.

]The most effective grinding of the mineral feed occurs in the layer under pressure, when all particles filling the voids between the balls are involved in a force interaction with the transfer of energy from the grinding media. In wet grinding, the presence of pelite fractions contributes to the intensive fracture development due to wedging while reducing strength through the Rebinder effect.

An analysis of the dependences of the $-100 \mu \mathrm{m}$ class formation on the filling ratio of the free space between the balls with the material being crushed showed that when the filling is insufficient, the grinding performance decreases.

Taking this circumstance into account for a number of crushing circuits involving drum mills will make it possible to evaluate the uniformity of grinding energy distribution between the successive stages.

\section{Methodology for assessing the rational grinding energy distribution in ball mills}

Before the end of the previous century, ball mills were widely used for ore grinding in comminution circuits. Twostage circuits were used more often than others, where the mills of the first stage were part of a closed loop with spiral classifiers, while those of the second stage were part of a closed loop with hydrocyclones. A common method for estimating the performance of ball mills was the Bond method, which was supplemented and improved by many authors for operation in specific process conditions [29], [30].

Considerable attention is paid to the intensification of ore grinding processes, since over $70 \%$ of the energy consumption for preparing the ores for concentration is accounted for by disintegration processes. One of the main grinding performance indicators in ball mills is the specific throughput $q_{d}$ according to the newly formed design size $-d$ :

$$
q_{d}=\left(\frac{Q}{V}\right)\left(\beta_{d}-\alpha_{d}\right)=q_{0} \Delta \beta_{d}=q_{0}^{+} \Delta \beta
$$

where:

$Q$ - the mill performance based on initial material, $\mathrm{t} / \mathrm{h}$;

$V$ - the effective volume of the mill;

$q_{0}-$ the specific feeding with initial material (feeding rate per unit mill volume with new initial material $), \mathrm{t} /\left(\mathrm{m}^{3} \cdot \mathrm{h}\right)$;

$q_{0}^{+}=q_{0}\left(1-\alpha_{d}\right)$ is the specific feeding with initial material of the coarse $+d$;

$\Delta \beta=\beta_{d^{-}} \cdot \alpha_{d}$ - the increase in the share of the design size;

$\beta_{d}$-the relative share of the design size in the grinding material;

$\alpha_{d}$ - the same for the initial mineral feeding [8].

The indicated parameter $q_{d}$ is a technological characteristic unrelated to energy inputs describing only the formation of the designed size class, without taking into account the formation of other larger classes, which appear simultaneously with the designed one. 
A very important characteristic is the energy efficiency of grinding $e_{d}(\mathrm{t} / \mathrm{kW} \cdot \mathrm{h})$ calculated on the newly formed designed size $-d$ :

$$
e_{d}=\frac{Q\left(\beta_{d}-\alpha_{d}\right)}{N}=\frac{q_{d} V}{N}=\frac{q_{d}}{N_{v}},
$$

where:

\section{$d$ - the design size;}

$N$ - the power consumed by the mill;

$N_{v}$ - the specific power consumed by the mill engine, $\mathrm{kW} / \mathrm{m}^{3}$.

From formula (7) it follows that at $N=$ const the energy efficiency of grinding is proportional to the specific throughput of the grinding mill on the newly formed class of the same size, i.e. $e_{d} \approx q_{d}$. The latter is widely used in calculating the mills performance and evaluating their work. The considered indicator can also serve as an economic criterion in assessing unit costs, but, like the specific productivity on the newly formed size, it evaluates the grinding process only in terms of one design size class.

The regularity of decreasing the content of the coarse class share, and the regularity of reducing the grinding product size, is associated with the formation of a new surface. New surface formation depends on the grinding process as a whole, and not only on the formation of the final design class. An important parameter, along with the formation rate of the final class, is the formation rate of a new surface. The formation of a new surface is due to a decrease in the particle size of the material to be ground. These geometrical properties of solid particles are interconnected:

$S a=6 V$,

where:

$S$ - the surface area of the mineral particle;

$a$ - the average particle size;

$V$ - the volume of the particle.

By differentiating the equation (8) with respect to time, we obtain the relationship of the geometrical values characterizing the grinding process:

$$
\frac{d(S a)}{d t}=\frac{d S}{d t} a+S \frac{d a}{d t}=0
$$

where:

$S$ - the area of the newly formed surface of particles approximated by a spherical shape; $a$ is the particle size (diameter);

$\frac{d S}{d t}$ - the formation rate of a new surface in the process of particles breakage;

$$
\frac{d a}{d t} \text { - the rate of change of the particle size (diameter). }
$$

It was also taken into account that in steady-state conditions, the time derivative of the volume $V$ of the solid mineral charge in the mill is equal to zero.

Using $S=\frac{d S}{d t}$ and $a=\frac{d a}{d t}$, after the termwise division by the product $S a$, equation (9) takes the form:

$$
\frac{\dot{S}}{S}=-\frac{\dot{a}}{a}
$$

The increase rate of the newly formed total particle surface $\dot{S}=\frac{d S}{d t}$ and the change rate of the particle size $\dot{a}=\frac{d a}{d t}$ must have different signs, i.e. a decrease in the size (diameter) of the particles in the steady state of the mill is inevitably accompanied by an increase in the newly formed total surface.

The above relationships clearly show that the formation rates of new classes during grinding and the formation rate of new surface are of the same order of magnitude. However, evaluating the grinding performance of a mill on the newly formed classes is possible by considering only one of them [8]. In practice, the assessment of specific indicators uses a class ready for concentration. But estimating specific throughput and specific grinding efficiency on the final size alone does not take into account the grinding kinetics of other classes, whose formation contributes to the total surface growth. Of particular relevance is the reliability of the comparative analysis of mills' performance at various stages of grinding. The influence of the diameter of grinding media on the parameters of the rate of destruction in ball mills is presented in [31]. Rational distribution of grinding energy between stages is a very important component of technological regulation of grinding sections and reducing specific energy costs [32]. Obviously, the newly formed surface is an indicator of grinding, taking into account all classes. State-of-the-art test data calculation and processing methods have allowed developing a program for calculating not only the total surface, but also the surface formed in each class. Total surface in combination with energy consumption indicators can be used to measure quantitative grinding performance, and the surface formed in individual size can be used to study grinding kinetics.

To assess energy efficiency, considering formation of all sizes, we introduce the concept of "grindability index", calculated according to the newly formed surfaces. Grindability index $I_{S}$ is interpreted as the ratio of the newly formed surface area $\Delta S$ to the unit of energy consumed by the mill, $N$ :

$$
I_{S}=\frac{\Delta S}{N}
$$

Grindability index in the presented form is a dimensional quantity which makes it possible to quantify the work required for grinding in a ball mill, based on the area of the newly formed surfaces:

$$
\Delta S=S_{d c h}-S_{c h},
$$

where:

$S_{d c h}$ - the total surface area of the solids in the discharge of the mill;

$S_{c h}$ - the total surface area of the mill feed, including the surface area of the mineral feed and the circulating load.

In grinding circuits where mills operate in a closed loop with classifiers of any type, the surface area of the circulating load should be excluded from the total surface areas of the discharge and feed. In the steady state, classifier outflow is a circulating load characterized by a constant particle size distribution.

Thus, in mills of the first grinding stage operating in a closed loop with spiral classifiers, the area of the newly formed surface $\Delta S_{1}$ is:

$\Delta S_{1}=S_{o f}-S_{f}$ 
where:

$S_{o f}-$ the surface area of the solids in the spiral classifier outflow;

$S_{f}$ - the surface area of the mill feed.

Similarly, the grindability index can be calculated for mills of the second and subsequent stages.

The released energy of the surface formed by the breakage of mineral particles in drum mills is proportional to the energy spent on grinding, i.e., proportional to the mill power intake in the steady state. Consequently, the area of the newly formed surface (regardless of the size) is proportional to the energy (power intake) consumed on its production. Thus, the grindability index of a mill can be found by summing the grindability indices of individual size classes.

In practical calculations, instead of the power needed to form a new surface, a proportional constant value of the power consumed by the mill is used. Obviously, a large share of the consumed power is converted into thermal energy and also spent on the accumulation of internal defects in the mineral feed. However, such an approximation is quite acceptable, since we need to determine energy consumption at various grinding stages. In this case, a systematic error is introduced, which does not significantly affect the comparison of the obtained results, since the above-mentioned power loss during grinding is equally characteristic of ball mills both in the first and subsequent grinding stages.

\section{Energy distribution of two-stage grinding}

An assessment of the rational distribution of the grinding energy between the stages is considered using an example of the Talnakh Concentrator Plant (TCP), whose first stage of grinding uses SAG mills MSHRGU $-4.5 \times 6.0$, while the second stage uses ball mills - MSHC $4.5 \times 6.0$. Spiral classifier $1 \mathrm{KSN}-24$ operates in a closed loop with a first stage mill, and for classifying the discharge of the mills of the second stage, two hydrocyclones GC-660 or one hydrocyclone GC-1000 are used.

When determining the grindability index of the TCP mills by particle size distribution, the following inputs were adopted: mineral feed density $\rho=3950 \mathrm{~kg} / \mathrm{m}^{3}$; mill engine power of the first grinding stage is $2125 \mathrm{~kW}$; mill engine power of the second stage is $1500 \mathrm{~kW}$; estimated time of a steady state is $1 \mathrm{~h}$. Based on the calculations, cumulative graphs were plotted for the given performance (Fig. 3).

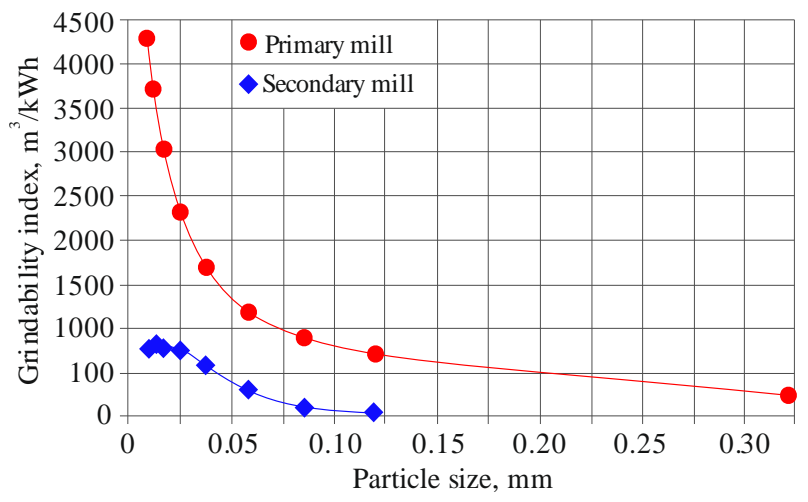

Figure 3. Cumulative grindability indices of the first and second stages mills at the TCP in a closed loop circuit with a spiral classifier
The formation of new surface in the size class $-0.015 \mathrm{~mm}$ is accompanied by a decrease in the breakage rate and the formation of refractory sludge in the mills of the first grinding stage. Examination of the cumulative graphs in Figure 3 shows that new surface formation in the mills of the first and second stages of grinding follows a similar pattern. The formation rate of the new surface in the second stage mills (combined grind ability index $I_{S 2}=640 \mathrm{~m}^{2} / \mathrm{kWh}$ ), and therefore the grinding performance, is much lower than in the first stage mills $\left(I_{S 1}=4300 \mathrm{~m}^{2} / \mathrm{kWh}\right)$, i.e. there exists a clear imbalance in the distribution of process flows between the first and second stages.

The cumulative graphs of the grindability indices by size classes indicate that the new surface forms to a greater extent due to the formation of the fine and final size classes, which is also confirmed by the angle of the tangent to the grindability curves, which characterizes the surface formation rate in the corresponding size classes. An elevated value of the grindability index in the first stage mill indicates that the mill is overloaded by the fine size classes of circulating load.

The absence of coarser size classes in the second stage mill leads to a decrease in the combined grindability index and grindability indices across all classes. Insufficient amount of feed reaching the second stage mills prevents the operation of the mechanism of particle breakage within the layer. To increase the grindability index of the second stage mills, coarser size classes should be fed into these mills. In addition, an important condition for improving the separation performance of the grinding product in hydrocyclones, and therefore the grade of the final product ready for concentration, is the method of controlling the hydrocyclones. Given the unevenness and heterogeneity of the product fed to the classifiers, methods for automatic control of hydrocyclones have been developed and are successfully applied in practice [32].

In this regard, a very important ore preparation task is minimization or complete elimination of final size classes in the ore mill feed. To fully load the second stage mills, one needs to remove, with maximum efficiency, from the circulating load of the first stage mills final and fine size classes in the amount sufficient to feed the hydrocyclone underflow to the second stage mill in the quantity necessary for complete grinding. Increasing the load on the second stage mill will lead to a decrease in the circulating load in the first stage, which, in turn, will increase yield calculated according to the original feed. One of the factors controlling the possibility of reducing the likelihood of overgrinding at different stages of comminution is the mineralogical and geochemical composition of the feed ore [33]. Moreover, depending on the physic and mechanic properties of the ores, one should take into account the linearity of the destruction particle process in grinding systems [34].

\section{Example and results of using drum classifiers in grinding circuits}

Changes in the quantitative parameters of the initial mineral feed and the circulating charge in grinding mills can be achieved by installing new types of auxiliary equipment.

One of the cost-effective ways to intensify grinding is to use hydraulic drum screens to separate by size the grinding pro-ducts of the first stage mills, instead of spiral classifiers [15], [16]. 
In comminution circuits, spiral classifiers performed the functions of classifying the mill grinding product by size and transporting the circulating charge. With the installation of hydraulic classifiers, for example, drum ones, the transportation of the circulating charge using spiral classifiers becomes impractical, because of the cumbersome design, on the one hand, and the increased energy consumption, on the other. The most cost-effective solution for delivering the circulating charge into the first stage mills are hydraulic transport systems using jet pumps.

When testing the grinding section with a drum classifier, five tests were performed at the Talnakh Concentrator Plant. The tests were carried out under steady-state conditions at the following process locations: initial mineral feed (ore mill feed), drum classifier discharge (size $-3 \mathrm{~mm}$ ), drum classifier outflow (size $+3 \mathrm{~mm}$ ), hydrocyclone outflow, discharge of the mill No. 2.

Test data (Fig. 4) indicated that the drum classifier design ensured complete recovery of the final size classes from the circulating load and significant (up to 96\%) recovery of size classes finer than $3 \mathrm{~mm}$. The content of the size class $-0.045 \mathrm{~mm}$ in the drum classifier discharge was $33.42 \%$ at $Q=180 \mathrm{t} / \mathrm{h}$ and $32.19 \%$ at $Q=205 \mathrm{t} / \mathrm{h}$. The content of the finial size class in the hydrocyclone discharge increased from 66.0 to $70.88 \%$. The performance of classification by size in the hydrocyclones increased from $41.62 \%$ in the existing layout to $55.1 \%$ at $Q=180 \mathrm{t} / \mathrm{h}$ and $50.33 \%$ at $Q=205 \mathrm{t} / \mathrm{h}$. A positive result is also an increase in the specific productivity of the sand mill based on the newly formed design size class finer than $0.045 \mathrm{~mm}$ from 0.40 to 0.73 and $0.93 \mathrm{t} / \mathrm{m}^{3} \mathrm{~h}$ and an increase in the specific throughput of the mill based on mineral feed from 0.99 to 3.92 and $4.51 \mathrm{t} / \mathrm{m}^{3} \mathrm{~h}$ respectively.

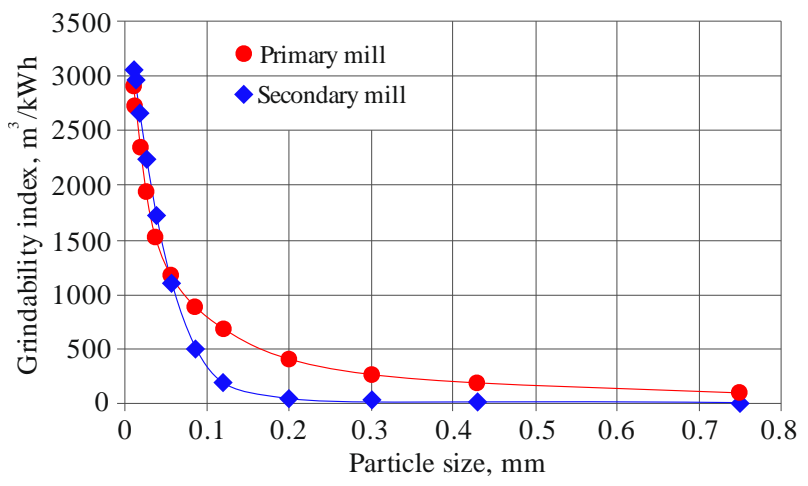

Figure 4. Cumulative grindability indices of the first and second stages mills at the TCP in a circuit with a drum classifier

In addition, the share of $-0.015 \mathrm{~mm}$ refractory sludge in the discharge of the hydrocyclone when using the drum classifier decreased from 33.72 to $21.68 \%$ and $20.01 \%$, which allows to expect further reduction in the valuable component losses.

According to technological trials at a given throughputs the grindability indices calculations were performed. When determining the grindability index by particle size distribution, the following input values were adopted: density of the recyclable material $\rho=4000 \mathrm{~kg} / \mathrm{m}^{3}$; power intake of the mill engine of the first grinding stage $N=2180 \mathrm{kWh}$ at $Q=180 \mathrm{t} / \mathrm{h}, N=2420 \mathrm{kWh}$ at $Q=205 \mathrm{t} / \mathrm{h}$; power intake of the mill engine of the second stage $N=1800$ and $1820 \mathrm{kWh}$, respectively; design time to steady state $t=1 \mathrm{~h}$.
A comparison of the grinding indices by stages shows that the drum classifier redistributed grinding energy between the stages, which can be considered rational: grindability index values of the first and second stage mills are practically the same $\left(I_{S 1}=2835-2934 \mathrm{~m}^{2} / \mathrm{kWh}\right.$ and $I_{S 2}=2867-3068 \mathrm{~m}^{2} / \mathrm{kWh}$, respectively) comparing with the similar values obtained prior to using the drum classifier $\left(I_{S 1}=3998 \mathrm{~m}^{2} / \mathrm{kWh}\right.$ and $\left.I_{S 2}=2039 \mathrm{~m}^{2} / \mathrm{kWh}\right)$. Freeing the first stage mill from the unnatural regrinding role and the resulting increased load on the second stage mills leads to a decrease in the grindability index in the first stage mills and an increase of this index in the second stage mills.

To compensate for the reduction in the grinding index in the first stage mills when using hydraulic classifiers, process fine-tuning should involve sending part of the hydrocyclone underflow together with the circulating load to the first stage mills. A process flowchart showing the possibility of redistributing the process flows in the mill feed is shown in Figure 5.

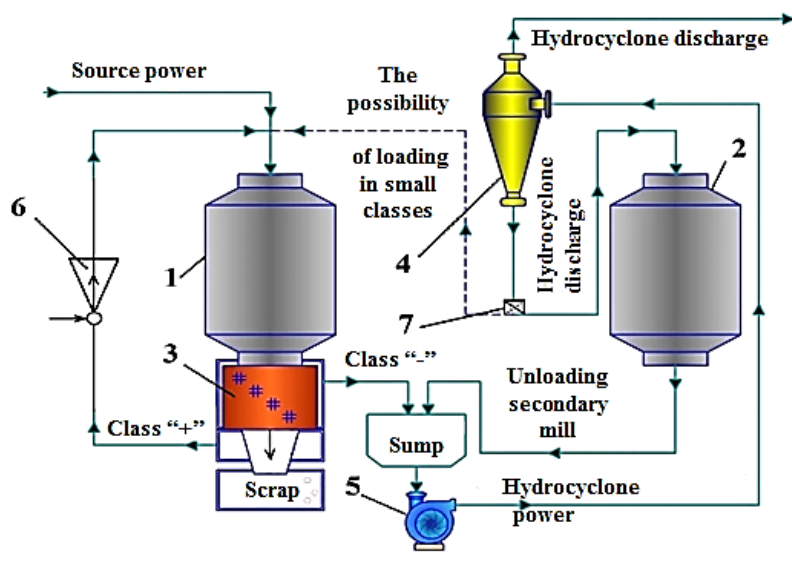

Figure 5. Grinding circuit using a drum classifier: 1 -first stage mill; 2 -second stage mill; 3 -drum classifier with a magnetic system; 4 -hydrocyclone; 5 - centrifugal pump; 6-hydrojet pump; 7 -Jones sampler

In the presented flowchart, the return of circulating load into the first stage mill is implemented at the Norilsk factory with the help of a jet pump instead of a spiral classifier.

Thus, the drum classifier made it possible to redistribute the load between the mills of the first and second stages, ensuring that the mills of the second stage are fed coarser size classes supporting the filling ratio necessary for complete grinding.

Thus, the use of a drum classifying device made it possible to redistribute the load between the mills of the first and second stages, ensuring that the mills of the second stage are fed coarser size classes supporting the filling ratio necessary for complete grinding. To recover fine size classes from the grinding product of the first stage mills with a high efficiency, other types of hydraulic screens can be used along with drum screens, for example DERREK screens.

\section{Conclusions}

The most intensive mineral raw materials grinding occurs in the layer under pressure, when the mineral particles force interaction occurs with energy transfer from the milling bodies at a discrete sliding between the layers along the ascending trajectories. Impact grinding takes place in the toe zone between the interacting balls and also between the balls and the lining. 
The developed technique allows finding a rational distribution of grinding energy in ball mills between successive stages introducing the concept of grinding index according to a newly formed class.

A new method for redistribution of grinding energy between ball mills of the first and second grinding stages using a hydraulic drum screen has been proposed and implemented in practice.

The nearest research task is establishing correlated dependencies between the ball mills and other types of grinding devices, including the SAG mills of the wet grinding and high pressure grinding rolls, to determine the rational distribution of grinding energy between sequential stages.

\section{Acknowledgements}

The studies were carried out under the contracts with the company CJSC "Zapolyarny filial Norilsk Nickel” (Russian Federation), Zangezur Mining and Processing Plant (Republic of Armenia) and Almalyk Mining and Metallurgical Plant (Republic of Uzbekistan).

The authors are grateful to Prof. Ciril O'Connor, President of the International Minerals Processing Congress, Center for Minerals Research, University of Cape Town (South Africa), Academician of RAS, Prof. V.A. Chanturia, for the comprehensive support of the scientific research related to the intensification of the processes associated with ore preparation for concentration. The authors extend their thanks to NPK "Mekhanobr-tekhnika" and LLC "Resurs" for the provided base and assistance in organizing experimental studies, as well as to all employees of the above mentioned organizations, who had participated in implementation of the studies at enterprises of the industry.

\section{References}

[1] Antsiferov, A.V., Zubkova, V.T., Kameneva, S.A., Svetkina, E.Y., \& Franchuk, V.P. (1998). The use of vertical vibrating mill for grinding and mixing of components of carbide steel. Xiaoxing Weixing Jisuanji Xitong/Mini-Micro Systems, 19(12), 4-8.

[2] Van der Wielen, K.P., Pascoe, R., Weh, A., Wall, F., \& Rollinson, G. (2013). The influence of equipment settings and rock properties on high voltage breakage. Minerals Engineering, 46-47, 100-111. https://doi.org/10.1016/j.mineng.2013.02.008

[3] Franchuk, V.P., \& Svetkina, E.Y. (1993). Peculiarities of silicon and titanium carbide grinding in the vibrating mill. Poroshkovaya Metallurgiya, (2), 5-7.

[4] Reichert, M., Gerold, C., Fredriksson, A., Adolfsson, G., \& Lieberwirth, H. (2015). Research of iron ore grinding in a vertical-roller-mill. Minerals Engineering, (73), 109-115. https://doi.org/10.1016/j.mineng.2014.07.021

[5] Pilov, P., Gorobets, L., \& Pryadko, N. (2009). Research of acoustic monitoring regularities in a jet grinding process. Archives of Mining Sciences, 54(4), 841-848.

[6] Shcherbakov, P., Tymchenko, S., Buhrym, O., \& Klymenko, D. (2019). Research into the crushing and grinding processes of iron ore with its simultaneous effect by mechanical load and electric field of ultra-high frequency. E3S Web of Conferences, (123), 01030. https://doi.org/10.1051/e3sconf/201912301030

[7] Gupta, V.K., \& Sharma, S. (2014). Analysis of ball mill grinding operation using mill power specific kinetic parameters. Advanced Powder Technology, 25(2), 625-634. https://doi.org/10.1016/j.apt.2013.10.003

[8] Pivnyak, G.G., Vaysberg, L.A., Kirichenko, V.I., Pilov, P.I. \& Kirichenko, V.V. (2007). Izmel'chenie. Energetika i tekhnologiya. Moskva, Rossiya: Ruda i metally.

[9] Pivnyak, G.G., Beshta, A.S., \& Khilov, V.S. (2004). Control of a drive rotation and milling cutter drilling on a basis of asymptotic identifier of state. Elektrotekhnika, (6), 42-45.

[10] Pivnyak, G.G., Kirichenko, V.I., Pilov, P.I., Kirichenko, V.V., Borodai, V.A. (2011). Creation of new generation energy-intensive tumbling mill. Metallurgical and Mining Industry, 3(4), 169-172.
[11] Kanda, Y., Simodaira, K., Kotake, N., \& Abe, Y. (1999). Experimental study on the grinding rate constant of a ball mill: effects of feed size and ball diameter. KONA Powder and Particle Journal, 17(0), 220-226. https://doi.org/10.14356/kona.1999030

[12] Soda, R., Sato, A., Kano, J., \& Saito, F. (2014). Development of prediction method of wear rate during wet stirred milling by using DEM. Journal of the Society of Powder Technology, Japan, 51(6), 436-443. https://doi.org/10.4164/sptj.51.436

[13] Monov, V., Sokolov, B., \& Stoenchev, S. (2012). Grinding in ball mills: modeling and process control. Cybernetics and Information Technologies, 12(2), 51-68. https://doi.org/10.2478/cait-2012-0012

[14] Malyarov, P.V., Kovalev, P.A. Bochkarev, A.V., \& Dolgov, A.M. (2018). Issledovanie vliyaniya mekhanizmov razrusheniya mineral'nogo syr'ya v sharovykh mel'nitsakh. Obogashchenie Rud, (3), 3-8.

[15] Malyarov, P.V., Stepurin, V.F., Soldatov, G.M., \& Konnik, N.D. (2006). Pereraspredelenie energii izmel'cheniya mezhdu stadiyami v usloviyakh Urupskogo GOKa. Obogashchenie Rud, (3), 18-20.

[16] Malyarov, P.V., Soldatov, G.M., Kaytmazov, N.G., Baskaev, P.M., Ivanov, V.A., \& Kotenev, D.V. (2008). Intensifikatsiya protsessov izmel'cheniya v usloviyakh Talnakhskoy obogatitel'noy fabriki. Obogashchenie Rud, (6), 6-10.

[17] Dortman, N.B. (1984). Fizicheskie svoystva gornykh porod i poleznykh iskopaemykh (Petrofizika). Moskva, Rossiya: Nedra.

[18] Abisheva, Z.S., Blaida, I.A., Ponomareva, E.I., \& Rozen, A.M. (1995). Effect of amine structure on gallium extraction from hydrochloric acid solutions. Hydrometallurgy, 37(3), 393-399. https://doi.org/10.1016/0304386x(94)00016-V

[19] Agapova, L.Y., Ponomareva, E.I., \& Abisheva, Z.S. (2001). Production of concentrated rhenium acid by electrodialysis of rhenium salts solutions. Hydrometallurgy, 60(2), 117-122. https://doi.org/10.1016/s0304386x(00)00192-4

[20] Abisheva, Z.S., Karshigina, Z.B., Bochevskaya, Y.G., Akcil, A., Sargelova, E.A., Kvyatkovskaya, M.N., \& Silachyov, I.Y. (2017). Recovery of rare earth metals as critical raw materials from phosphorus slag of long-term storage. Hydrometallurgy, (173), 271-282. https://doi.org/10.1016/j.hydromet.2017.08.022

[21] Fedotov, P. (2014). Simulation of particle size distribution of the ore destruction product in the particle layer. Proceedings of the XXVII International Mineral Processing Congress, (10), 1-10.

[22] Fedotov, P.K. (2014). Modelirovanie protsessa razrusheniya rudy v sloe chastits pod davleniem. Fiziko-Tekhnicheskie Problemy Razrabotki Poleznykh Iskopaemykh, (4), 71-77.

[23] Rakishev, B.R., \& Galiev, D. A. (2015). Optimization of the ore flow quality characteristics in the quarry in road-rail transport. Metallurgical and Mining Industry, 7(4), 356-362.

[24] Bargteil, A.W., \& Cohen, E. (2014). Animation of deformable bodies with quadratic Bezier finite elements. ACM Transactions on Graphics, 33(3), 1-10. https://doi.org/10.1145/2567943

[25] Stavrogin, A.N., \& Tarasov, B.G. (2001). Experimental physics and rock mechanics. United Kingdom: CRC Press, Taylor \& Francis Group.

[26] Tuzcu, E.T., \& Rajamani, R.K. (2011). Modeling breakage rates in mills with impact energy spectra and ultra fast load cell data. Minerals Engineering, 24(3-4), 252-260. https://doi.org/10.1016/j.mineng.2010.08.017

[27] Khopunov, E.A. (2016). Problemy modelirovaniya dezintegratsii rud. Sovremennye Nauchnye Issledovaniya i Innovatsii, (1), 1-11.

[28] Frydrýšek, K., \& Gondek, H. (2008). Finite element model of the ore disintegration process. Annals of the Faculty of Engineering Hunedoara - Journal of Engineering, 6(1), 133-138.

[29] Lvov, V.V., \& Chitalov, L.S. (2019). Comparison of the different ways of the ball Bond work index determining. International Journal of Mechanical Engineering and Technology (IJMET), 10(4), 285-299.

[30] Nikolaeva, N., Aleksandrova, T., \& Romashev, A. (2017). Effect of grinding on the fractional composition of polymineral laminated bituminous shales. Mineral Processing and Extractive Metallurgy Review, 39(4), 231-234. https://doi.org/10.1080/08827508.2017.1415207

[31] Erdem, A.S., \& Ergün, S.L. (2009). The effect of ball size on breakage rate parameter in a pilot scale ball mill. Minerals Engineering, 22(7-8), 660-664. https://doi.org/10.1016/j.mineng.2009.01.015

[32] Lvov, V.V., \& Aleksandrova, T.N. (2016). Automated control of hydrocyclone classification. Gornyi Zhurnal, (5), 94-96. https://doi.org/10.17580/gzh.2016.05.14

[33] Aleksandrova, T., Nikolaeva, N., Lieberwirth, H., \& Aleksandrov, A. (2018). Selective desintegration and concentration: theory and practice. E3S Web of Conferences, (56), 03001. https://doi.org/10.1051/e3sconf/20185603001

[34] Fuerstenau, D.W., De, A., \& Kapur, P.C. (2004). Linear and nonlinear particle breakage processes in comminution systems. International Journal of Mineral Processing, (74), S317-S327. https://doi.org/10.1016/j.minpro.2004.07.005 


\section{Механізми дезінтеграції мінеральної сировини в кульових млинах та розподіл енергії подрібнення між послідовними стадіями}

\section{П. Маляров, О. Долгов, П. Ковальов}

Мета. Вивчення механізму руйнування частинок мінеральної сировини, раціонального розподілу енергії подрібнення в кульових млинах між послідовними стадіями і розробка інженерних способів перерозподілу технологічних потоків в схемах подрібнення для зниження питомих витрат енергії.

Методика. Для експериментального дослідження механізму дезінтеграції використовувалася фізична модель кульового млина при періодичному подрібненні з урахуванням теорії подібності. Для порівняльних досліджень сухого і мокрого подрібнення застосовувався кварцовий пісок і продукти дробленого мармуру розміром $(+0.25 \ldots-0.5)$ мм. Вибір раціональних параметрів розподілу енергії подрібнення між послідовними стадіями кульового подрібнення виконувався шляхом генеральних випробувань на збагачувальних підприємствах Вірменії, Росії та Узбекистану.

Результати. Представлено матеріали досліджень процесів подрібнення в кульових млинах. Встановлено, що руйнування частинок мінеральної сировини в кульових млинах відбувається в шарі при дискретному ковзанні шарів кульового завантаження на траєкторіях підйому при ефективному заповненні вільного простору між кулями матеріалом що подрібнюється. Розроблено методику оцінки ефективності розподілу енергії подрібнення між послідовними стадіями на основі встановлених закономірностей механізмів руйнування частинок мінеральної сировини. Запропоновано способи перерозподілу енергії подрібнення між першою і другою стадіями подрібнення. Розроблено та реалізовано в практиці збагачувальних підприємств способи раціонального розподілу енергії подрібнення між млинами першої та другої стадій за допомогою барабанних грохотів.

Наукова новизна. Встановлено залежності вмісту подрібненого матеріалу класу -100 мкм від коефіцієнта наповнення вільного простору матеріалом, що подрібнюється для піску і мармуру при сухому і мокрому подрібненні. Розкрито механізм руйнування частинок мінеральної сировини в шарі при дискретному ковзанні між шарами завантаження на траєкторіях підйому.

Практична значимість. Запропонована методика оцінки ефективності розподілу енергії подрібнення дозволила розробити $\mathrm{i}$ впровадити в практику збагачувальних підприємств способи перерозподілу енергії подрібнення між послідовними стадіями 3 суттєвим економічним ефектом.

Ключові слова: млин, подрібнення, проковзування, енергія подрібнення, барабанний грохот

\section{Механизмы дезинтеграции минерального сырья в шаровых мельницах и распределение энергии измельчения между последовательными стадиями}

\section{П. Маляров, А. Долгов, П. Ковалёв}

Цель. Изучение механизма разрушения частиц минерального сырья, рационального распределения энергии измельчения в шаровых мельницах между последовательными стадиями и разработка инженерных способов перераспределения технологических потоков в схемах измельчения для снижения удельных расходов энергии.

Методика. Для экспериментального исследования механизма дезинтеграции использовалась физическая модель шаровой мельницы при периодическом измельчении с учетом теории подобия. Для сравнительных исследований сухого и мокрого измельчения применялся кварцевый песок и продукты дробленого мрамора крупностью $(+0.25 \ldots-0.5)$ мм. Выбор рациональных параметров распределения энергии измельчения между последовательными стадиями шарового измельчения выполнялась путем генеральных опробований на обогатительных предприятиях Армении, России и Узбекистана.

Результаты. Представлены материалы исследований процессов измельчения в шаровых мельницах. Установлено, что разрушение частиц минерального сырья в шаровых мельницах происходит в слое при дискретном скольжении слоев шаровой загрузки на траекториях подъема при эффективном заполнении свободного пространства между шарами измельчаемым материалом. Разработана методика оценки эффективности распределения энергии измельчения между последовательными стадиями на основе установленных закономерностей механизмов разрушения частиц минерального сырья. Предложены способы перераспределения энергии измельчения между первой и второй стадиями измельчения. Разработаны и реализованы в практике обогатительных предприятий способы рационального распределения энергии измельчения между мельницами первой и второй стадий с помощью барабанных грохотов.

Научная новизна. Установлены зависимости содержания измельченного материала класса -100 мкм от коэффициента наполнения свободного пространства измельчаемым материалом для песка и мрамора при сухом и мокром помоле. Раскрыт механизм разрушения частиц минерального сырья в слое при дискретном скольжении между слоями загрузки на траекториях подъема.

Практическая значимость. Предложенная методика оценки эффективности распределения энергии измельчения позволила разработать и внедрить в практику обогатительных предприятий способы перераспределения энергии измельчения между последовательными стадиями с большим экономическим эффектом.

Ключевые слова: мельница, измельчение, проскальзывание, энергия измельчения, барабанный грохот

\section{Article info}

Received: 7 June 2019

Accepted: 30 March 2020

Available online: 18 April 2020 